\title{
Acholeplasma brassicae sp. nov. and Acholeplasma palmae sp. nov., Two Non-Sterol-Requiring Mollicutes from Plant Surfaces
}

\author{
JOSEPH G. TULLY, ${ }^{1 *}$ ROBERT F. WHITCOMB,${ }^{2}$ DAVID L. ROSE,${ }^{1} \dagger$ JOSEPH M. BOVÉ, ${ }^{3}$ PATRICIA CARLE, ${ }^{3}$ \\ NORMAN L. SOMERSON,${ }^{4} \ddagger$ DAVID L. WILLIAMSON,${ }^{5}$ AND SIMON EDEN-GREEN ${ }^{6}$ \\ Mycoplasma Section, National Institute of Allergy and Infectious Diseases, Frederick Cancer Research and \\ Development Center, Frederick, Maryland 217021; Insect Biocontrol Laboratory, U.S. Department of Agriculture, \\ Beltsville, Maryland 207052; Laboratoire de Biologie Cellulaire et Moléculaire, Institut National Recherche \\ Agronomique and Université de Bordeaux II, 33883 Villenave d'Ornon Cedex, France ${ }^{3}$; Department of Microbiology, \\ Ohio State University, Columbus, Ohio $43210^{4}$; Department of Anatomical Sciences, State University of New York, \\ Stony Brook, New York 117945; and National Resources Institute, Chatham, Kent, England ME4 4TB
}

\begin{abstract}
Two mollicutes (strains $\mathrm{O502}^{\mathrm{T}}$ [ $\mathrm{T}=$ type strain] and $\mathrm{J233}^{\mathrm{T}}$ ), which were isolated from the surfaces of broccoli (Brassica oleracea var. italica) plants or the crown tissues of the coconut palm (Cocos nucifera), were capable of sustained growth in serum-free (or cholesterol-free) mycoplasma broth media. Examination by electron and dark-field microscopic techniques revealed that the cells of each strain were small, nonhelical, nonmotile, pleomorphic, and coccoid and that each cell was surrounded by a single cytoplasmic membrane. No evidence of a cell wall was found. The organisms were filterable and grew rapidly in most conventional mycoplasma culture medium formulations containing horse or fetal bovine sera under either aerobic or anaerobic conditions. The optimum temperature for growth of both organisms was $30^{\circ} \mathrm{C}$, but multiplication occurred over a temperature range from 18 to $37^{\circ} \mathrm{C}$. Both strains catabolized glucose, but did not hydrolyze arbutin, arginine, or urea. The genome size of strain $0502^{\mathrm{T}}$ was $1,215 \mathrm{kbp}$, and the DNA base composition (guanine-plus-cytosine content) was $35.5 \mathrm{~mol} \%$. The genome size of strain $\mathrm{J}_{233^{\mathrm{T}}}$ was $1,610 \mathrm{kbp}$, and the DNA base composition was $30.0 \mathrm{~mol} \%$. The two isolates were not serologically related to each other or to the type strains of 11 previously described Acholeplasma species. Strain 0502 (= ATCC 49388) is the type strain of Acholeplasma brassicae sp. nov., and strain $\mathbf{J 2 3 3}$ (= ATCC 49389) is the type strain of Acholeplasma palmae sp. nov.
\end{abstract}

The presence of nonhelical, wall-less procaryotes (class Mollicutes) on plant surfaces was first documented in $1979(10$, 15) when what at the time were thought to be both sterolrequiring and non-sterol-requiring mollicutes were isolated from several tropical and subtropical plants. According to prevailing taxonomic concepts, all of the non-sterol-requiring organisms were regarded as Acholeplasma species. Indeed, some of the non-sterol-requiring isolates obtained from plant surfaces were later shown to be related to Acholeplasma species previously isolated from vertebrate hosts (e.g., Acholeplasma axanthum, Acholeplasma oculi, and Acholeplasma laidlawii) $(10,23)$. Other strains that grew in the absence of cholesterol or serum appeared to be members of putative new Acholeplasma species (5, 23, 25, 29, 31, 33).

The mollicutes from plants that appeared to be sterolrequiring organisms were at first referred to the genus $\mathrm{Myco}$ plasma. Subsequent research, however, showed that the members of this group belonged to two distinct clusters, neither of which consisted of true Mycoplasma species. The strains in one cluster were mollicutes that, although they were not able to grow in a serum-free base broth medium, grew rapidly and continuously if small amounts $(0.04 \%)$ of polyoxyethylene sorbitan monooleate (Tween 80 ) were added to the base medium $(21,25,31,33)$. Later, a large number of strains that had similar growth requirements were isolated from other plant and insect hosts from temperate regions. At first, these strains were mistaken for acholeplasmas, because Tween 80

\footnotetext{
* Corresponding author. Mycoplasma Section, NIAID, Bldg. 550, Frederick Cancer Res. Dev. Center, Frederick, MD 21702. Phone: (301) 846-1192. Fax: (301) 846-5165.

$\dagger$ Present address: 8602 Cinnamon Creek, San Antonio, TX 78284. $\ddagger$ Deceased.
}

could apparently replace sterol in the growth media used. However, this cluster of organisms was eventually shown to be phylogenetically distinct from the acholeplasmas (34). At the present time, these strains have been placed in 11 species, all of which have been assigned to the recently proposed new genus Mesoplasma in the class Mollicutes $(30,32)$.

Extensive studies of the second group of plant isolates showed that these mollicutes had more strict growth requirements for cholesterol or serum; no growth stimulation was observed after addition of Tween 80 to serum-free media. Later, additional mollicutes with similar nutritional needs were isolated from plants and insects in temperate regions (36). Five new species were recognized within this cluster of mollicutes, and recently these organisms were assigned to a second new genus (Entomoplasma) in the class Mollicutes (30).

Two of the plant surface strains obtained in the 1979 (10) and 1982 (23) studies have been examined further to confirm the initial identification of these organisms as true Acholeplasma species. In this report, we describe the properties of these strains and propose that these organisms should be designated new Acholeplasma species.

\section{MATERIALS AND METHODS}

Mycoplasma strains. Strain $0502^{\mathrm{T}}(\mathrm{T}=$ type strain) was isolated from broccoli plants in Columbus, Ohio, in 1982 (23). Strain $\mathrm{J} 233^{\mathrm{T}}$ was derived from an isolate (originally designated E847) obtained from crown tissues of a coconut palm infected with lethal yellowing disease in Jamaica in 1978 (10). A triply cloned (26) culture of strain $\mathrm{J}_{233^{\mathrm{T}}}$ was prepared in England and subsequently was deposited in the American Type Culture Collection as strain ATCC 33684. Later, this purified strain was used in a number of pathogenicity studies $(8,9)$. The original strain $\mathrm{J} 233^{\mathrm{T}}$ culture examined in the United States was 
triply cloned and later was also deposited in the American Type Culture Collection as strain ATCC $49389^{\mathrm{T}}$. Although strains $\mathrm{J}_{233^{\mathrm{T}}}$ and E847 are serologically identical and represent the same species, the characterization study described in this paper was carried out with cloned strain $\mathrm{J}_{233^{\mathrm{T}}}(=\mathrm{ATCC}$ $\left.49389^{\mathrm{T}}\right)$. Strain $0502^{\mathrm{T}}$ was also purified by conventional filtration-cloning techniques. The following type strains of previously described Acholeplasma species were used in various parts of this study and were obtained from the collection of the National Institute of Allergy and Infectious Diseases laboratory in Frederick, Md.: Acholeplasma axanthum S-743 ${ }^{\mathrm{T}}$, Acholeplasma cavigenitalium $\mathrm{GP}^{\mathrm{T}}$, Acholeplasma equifetale $\mathrm{C} 112^{\mathrm{T}}$, Acholeplasma granularum BTS39 ${ }^{\mathrm{T}}$, Acholeplasma hippikon $\mathrm{C1}^{\mathrm{T}}$, Acholeplasma laidlawii $\mathrm{PG}^{\mathrm{T}}$, Acholeplasma modicum $\mathrm{PG}^{4}{ }^{\mathrm{T}}$, Acholeplasma morum $72-043^{\mathrm{T}}$, Acholeplasma multilocale $\mathrm{PN} 525^{\mathrm{T}}$, Acholeplasma oculi $19 \mathrm{~L}^{\mathrm{T}}$, and Acholeplasma parvum $\mathrm{H}_{23} \mathrm{M}^{\mathrm{T}}$.

Culture medium and cultivation techniques. The general techniques used for isolating mollicutes from plant sources have been described previously (7). Strain $0502^{\mathrm{T}}$ was cultivated by washing plant tissue with SP-4 broth (35), filtering the wash fluid through a sterile 450-nm-pore-size membrane filter, and incubating the preparation at $37^{\circ} \mathrm{C}$. Strain $\mathrm{J} 233^{\mathrm{T}}$ was grown initially on conventional mycoplasma media supplemented with $10 \%$ horse serum (11), but growth also occurred in bovine serum fraction media (28) that were supplemented with or lacked $0.01 \%$ Tween 80 . Characterization studies were performed with either serum fraction or SP-4 broth media, containing $500 \mathrm{U}$ of penicillin per $\mathrm{ml}$. Solid media were prepared with $0.8 \%$ Noble agar (Difco Laboratories, Detroit, Mich.) and were incubated under aerobic and anaerobic conditions (GasPak system; BBL Microbiology Systems, Cockeysville, Md.).

An incubation temperature of $30^{\circ} \mathrm{C}$ was used throughout this study. The techniques used for determining the optimum growth temperatures and the temperature ranges for growth (from 10 to $37^{\circ} \mathrm{C}$ ) for the two strains (in SP-4 broth) have been described previously (36). Early passages of strains $0502^{\mathbf{T}}$ and $\mathrm{J} 233^{\mathrm{T}}$ were also maintained for at least five consecutive passages on horse serum broth that lacked penicillin and other antibiotics. At each subculturing, the organisms were plated onto conventional blood agar and incubated aerobically at $37^{\circ} \mathrm{C}$. After 2 to 10 days, the plates were examined for bacterial colonies and evidence of reversion.

Morphological studies. Strains $0502^{\mathrm{T}}$ and $\mathrm{J} 233^{\mathrm{T}}$ were grown overnight at $30^{\circ} \mathrm{C}$ in SP-4 broth, and the resulting logarithmicphase cultures were examined by dark-field microscopy, using a magnification of $\times 1,250$. For electron microscopic examination, each organism was grown in approximately $10 \mathrm{ml}$ of horse serum broth, and the cells were pelleted by centrifugation. The cell pellet was then fixed for $2 \mathrm{~h}$ in $3 \%$ glutaraldehyde, postfixed for $1 \mathrm{~h}$ in $1 \%$ osmium tetroxide, dehydrated in acetone, embedded in Epon-araldite, sectioned, and stained with $1 \%$ aqueous uranyl acetate and Reynold's lead citrate (36).

Sterol requirement. Growth requirements for sterol were determined by a standard broth culture method $(19,27)$, using serum-free broth medium supplemented with either $0.01 \%$ Tween 80 fatty acid mixture or cholesterol; various concentrations of cholesterol were tested. All of the broth cultures used in these tests were incubated at $30^{\circ} \mathrm{C}$. The protein contents of mycoplasma cell pellets were determined with a protein kit (Bio-Rad Laboratories, Richmond, Calif.).

Tests for biological and biochemical properties. The procedures used to study carbohydrate fermentation (1) and hydrolysis of arbutin (20), arginine, and urea (1) have been described

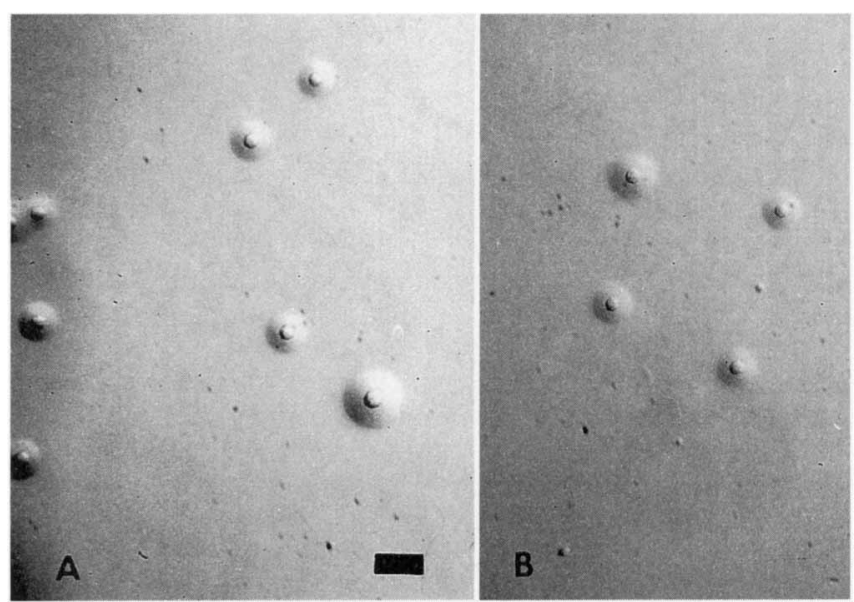

FIG. 1. Colonies of two acholeplasmas on $20 \%$ horse serum agar incubated for 3 days at $30^{\circ} \mathrm{C}$ under anaerobic conditions. (A) Strain $\mathrm{J}_{233^{\mathrm{T}}}$. (B) Strain $0502^{\mathrm{T}}$. Bar $=100 \mu \mathrm{m}$.

previously. The techniques used to assess filtration characteristics (26) and hemadsorption (12) also have been described previously.

Serological tests. Antiserum to strains $0502^{\mathrm{T}}$ and $\mathrm{J} 233^{\mathrm{T}}$ was raised in rabbits by using standard techniques (22). Hyperimmune antisera to all 11 previously described Acholeplasma species (see above) were obtained from the reference collection maintained at the National Institute of Allergy and Infectious Diseases laboratory in Frederick, Md. The antisera were used in standard disc growth inhibition tests (6) performed with strains $0502^{\mathrm{T}}$ and $\mathrm{J} 233^{\mathrm{T}}$ by using an agar medium containing $1 \%$ bovine serum fraction and anaerobic incubation at $30^{\circ} \mathrm{C}$. Direct agar plate immunofluorescence tests (13) were performed with strain $0502^{\mathrm{T}}$ or $\mathrm{J} 233^{\mathrm{T}}$ agar colonies and fluorescein-conjugated antisera to other acholeplasmas (see above).

Genomic analysis. The techniques used to extract and purify chromosomal DNAs from mollicutes and to determine genome sizes by pulsed-field gel electrophoresis have been described previously $(3,18)$. The guanine-plus-cytosine contents of the purified DNAs of strains $0502^{\mathrm{T}}$ and $\mathrm{J} 233^{\mathrm{T}}$ were determined by buoyant density, melting temperature, and high-pressure liquid chromatography (HPLC) methods (4). Purified DNA from Spiroplasma citri (genome size, approximately $1,780 \mathrm{kbp}$; base composition, $26 \mathrm{~mol} \%$ guanine plus cytosine) was used as a reference standard.

\section{RESULTS AND DISCUSSION}

Cultural and morphological properties. Strains $0502^{\mathrm{T}}$ and $\mathrm{J} 233^{\mathrm{T}}$ grew rapidly on mycoplasma medium formulations containing serum (fetal bovine serum or horse serum) or bovine serum fraction. Sustained growth also occurred in serum-free mycoplasma broth (21). Growth occurred over a temperature range of 18 to $37^{\circ} \mathrm{C}$, and optimum growth was observed at $30^{\circ} \mathrm{C}$. The colonies obtained on horse serum or SP-4 agar formulations exhibited typical fried-egg morphology (Fig. 1).

Logarithmic-phase cultures of strains $0502^{\mathrm{T}}$ and $\mathrm{J} 233^{\mathrm{T}}$ in SP-4 medium examined by dark-field microscopy contained predominantly coccoid forms. The cells sedimented from broth cultures and examined by electron microscopy also were predominantly coccoid. No evidence of a cell wall was observed in these preparations; the diameters of representative 

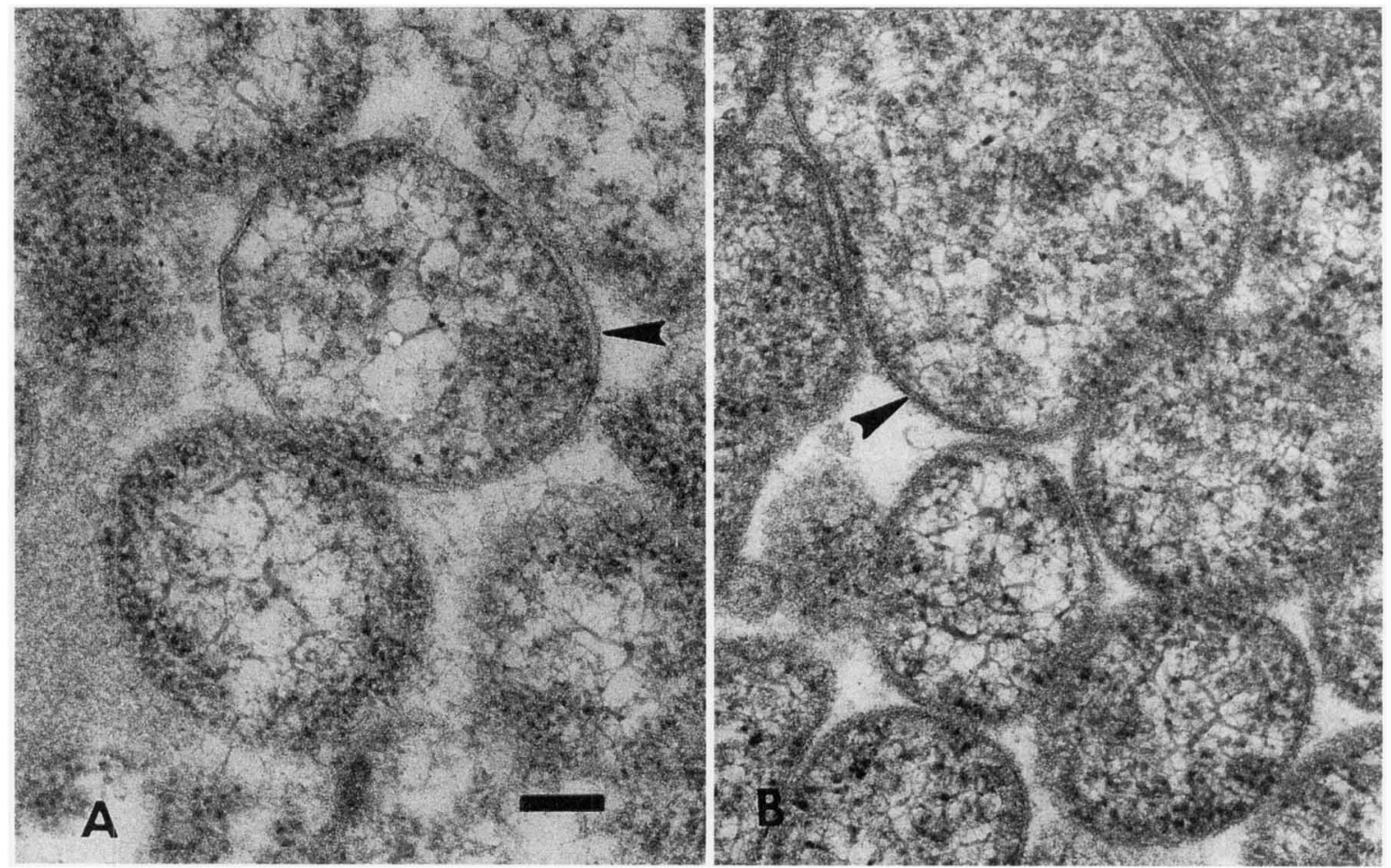

FIG. 2. Electron micrographs of sectioned and stained cell pellets of two acholeplasmas. The sections were stained with $2 \%$ aqueous uranyl acetate and Reynold's lead citrate. The arrowheads indicate the unit membrane. (A) Strain J233 ${ }^{\mathrm{T}}$. (B) Strain $0502^{\mathrm{T}}$. Bar $=100 \mathrm{~nm}$.

round cells varied from 300 to $500 \mathrm{~nm}$, and each cell was surrounded by a single cytoplasmic membrane (Fig. 2).

Sterol requirement. The growth responses of strains $0502^{\mathrm{T}}$ and $\mathrm{J}_{233^{\mathrm{T}}}$ in serum-free base media containing fatty acid or cholesterol supplements are shown in Table 1. Both strains exhibited some growth in the serum-free base broth alone and produced greater cell yields when this medium contained palmitic acid and albumin. The growth yields did not significantly increase when cholesterol was added. The lack of a sterol requirement for both strains was also observed in another study (21), in which these organisms were evaluated for sustained growth through 23 serial dilutions in media without serum.

Biochemical and biological properties. Both strain $0502^{\mathrm{T}}$

TABLE 1. Growth responses of strains $\mathrm{J}_{233^{\mathrm{T}}}$ and $0502^{\mathrm{T}}$ to cholesterol ${ }^{a}$

\begin{tabular}{|c|c|c|c|}
\hline \multirow{2}{*}{$\begin{array}{l}\text { Supplement(s) added to serum- } \\
\text { free base medium }\end{array}$} & \multirow{2}{*}{$\begin{array}{l}\text { Cholesterol } \\
\text { concn }(\mu \mathrm{g} / \mathrm{ml})\end{array}$} & \multicolumn{2}{|c|}{$\begin{array}{l}\text { Amt of protein } \\
(\mathrm{mg} / 100 \mathrm{ml})\end{array}$} \\
\hline & & $\begin{array}{l}\text { Strain } \\
0502^{\mathrm{T}}\end{array}$ & $\begin{array}{l}\text { Strain } \\
\text { J } 233^{\mathrm{T}}\end{array}$ \\
\hline Bovine serum fraction $(1 \%)$ & (Control) & 5.57 & 2.00 \\
\hline None & 0 & 1.28 & 0.94 \\
\hline $\begin{array}{l}\text { Albumin }(1 \%) \text { and palmitic } \\
\text { acid }(10 \mu \mathrm{g} / \mathrm{ml})\end{array}$ & 0 & 4.60 & 2.20 \\
\hline $\begin{array}{l}\text { Albumin, palmitic acid, and } \\
\text { Tween } 80(0.01 \%)\end{array}$ & 0 & 6.13 & 2.57 \\
\hline \multirow{4}{*}{$\begin{array}{l}\text { Albumin, palmitic acid, and } \\
\text { cholesterol }\end{array}$} & 1 & 5.97 & 1.63 \\
\hline & 5 & 6.38 & 1.38 \\
\hline & 10 & 5.97 & 1.40 \\
\hline & 20 & 6.38 & 1.40 \\
\hline
\end{tabular}

${ }^{a}$ All cultures were incubated at $30^{\circ} \mathrm{C}$. and strain $\mathrm{J} 233^{\mathrm{T}}$ rapidly fermented glucose, with consequent decreases in the $\mathrm{pH}$ values of the culture media. No evidence of mannose fermentation or hydrolysis of arbutin, arginine, or urea was observed. Strain $0502^{\mathrm{T}}$ and $\mathrm{J} 233^{\mathrm{T}}$ colonies on agar medium did not hemadsorb guinea pig erythrocytes. Filtration studies were performed with each strain. For strain $0502^{\mathrm{T}}$ the unfiltered control broth and the broth media after filtration through membranes having pore sizes of $450,300,220$, and 100 nm contained $1 \times 10^{9}, 1 \times 10^{9}, 1 \times 10^{8}, 1 \times 10^{3}$, and 0 color-changing units $/ \mathrm{ml}$, respectively; the corresponding values for strain $\mathrm{J}_{233^{\mathrm{T}}}$ preparations were $1 \times 10^{9}, 1 \times 10^{9}, 1 \times 10^{9}$, $1 \times 10^{6}$, and 0 color-changing units $/ \mathrm{ml}$, respectively. No evidence of reversion to bacterial forms was obtained with either strain.

Serological tests. Extensive growth inhibition and plate immunofluorescence tests, which were performed with antisera or conjugates to the previously described acholeplasmas, revealed that strains $0502^{\mathrm{T}}$ and $\mathrm{J} 233^{\mathrm{T}}$ were not related serologically to each other or to 11 previously described Acholeplasma species. Antisera prepared to $0502^{\mathrm{T}}$ and $\mathrm{J} 233^{\mathrm{T}}$ produced homologous growth inhibition zones that were 3 to $4 \mathrm{~mm}$ wide. In several previous studies of strain $\mathrm{J}_{233^{\mathrm{T}}}(9,10)$, we observed some low-level serologic cross-reactions in both growth inhibition and immunofluorescence tests between this organism and antisera or conjugates to strain $19 \mathrm{~L}^{\mathrm{T}}$ of $\mathrm{A}$. oculi. However, these results were not consistently reproducible, and other phenotypic markers (such as no arbutin hydrolysis) suggested that strain $\mathrm{J} 233^{\mathrm{T}}$ was not closely related to $A$. oculi strains.

Genomic analysis. The following genome sizes were determined by pulsed-field gel electrophoresis: strain $0502^{\mathrm{T}}, 1,215$ $\mathrm{kbp}$; and strain $\mathrm{J} 233^{\mathrm{T}}, 1,610 \mathrm{kbp}$. The DNA base compositions determined by the three techniques were $35.5 \mathrm{~mol} \%$ for strain $0502^{\mathrm{T}}$ and $30.0 \mathrm{~mol} \%$ for strain $\mathrm{J} 233^{\mathrm{T}}$. The genome sizes of the two organisms are consistent with the data in other reports 
which have indicated that the genome sizes of acholeplasmas range from 1,200 to $1,500 \mathrm{kbp}(2,16,17)$.

Recently, a phylogenetic study of strain $\mathrm{J} 233^{\mathrm{T}}$, in which a sequence analysis of a conserved protein gene (rps3) (24) was performed, indicated that this organism is closely related to $A$. laidlawii, thus providing additional support for classification of $\mathrm{J}_{233^{\mathrm{T}}}$ as a species in the genus Acholeplasma. This study was also of considerable interest since it showed that the plantpathogenic members of the class Mollicutes, which are called mycoplasmalike organisms or phytoplasmas, are more closely related to strain $\mathrm{J}_{233^{\mathrm{T}}}$ (and A. laidlawii) than to other members of the Mollicutes.

Habitat. At the present time, the two mollicutes characterized in this study are known only as inhabitants of plant surfaces. However, on the basis of previous experience, it is quite likely that one or more insect hosts will eventually be found to be colonized with each organism. The occurrence of mollicutes on plant surfaces probably results primarily from insect contamination of plant tissue during insect feeding excursions, and characterization and availability of specific reagents to identify such mollicutes frequently provide new information on the ecology of mollicutes (5).

In some previous studies, it was shown that strain $\mathrm{J}_{23} 33^{\mathrm{T}}$ infections in leafhoppers (Euscelidius variegatus) could be maintained for 2 to 3 weeks following experimental inoculation, although no evidence was obtained that the organism was pathogenic for the insect host $(8,9)$.

The following properties of strains $0502^{\mathrm{T}}$ and $\mathrm{J} 233^{\mathrm{T}}$ described in this paper fulfill the essential criteria (14) for placing species in the class Mollicutes: absence of a cell wall, filterability, lack of reversion to walled bacteria when the organisms are grown in antibiotic-free media, penicillin resistance, and production of typical colonial forms on agar. The lack of a growth requirement for sterol or serum and the lack of helicity place these organisms in the family Acholeplasmataceae and the genus Acholeplasma (28). Finally, a serologic comparison of the two strains with a collection of antisera to all previously described Acholeplasma species demonstrated that strains $0502^{\mathrm{T}}$ and $\mathrm{J} 233^{\mathrm{T}}$ are not related to other organisms in the genus.

We therefore propose that these two mollicutes should be designated new Acholeplasma species. The taxonomic descriptions below summarize the properties of each organism.

Description of Acholeplasma brassicae sp. nov. Acholeplasma brassicae (bras'si.cae. L fem. gen. n. brassicae, of cabbage, referring to the plant origin of the organism). Cells are primarily coccoid, ranging in diameter from 300 to $500 \mathrm{~nm}$. Cells lack true cell walls. Nonmotile. Colonies on solid medium containing $0.8 \%$ Noble agar usually have the appearance of fried eggs. Chemoorganotroph. Acid is produced from glucose. Does not hydrolyze arbutin, arginine, or urea. Agar colonies do not hemadsorb guinea pig erythrocytes.

Cholesterol or serum is not required for growth.

The temperature range for growth is 18 to $37^{\circ} \mathrm{C}$; optimum growth occurs at $30^{\circ} \mathrm{C}$.

Serologically distinct from other Acholeplasma species.

Isolated from broccoli (Brassica oleracea var. italica) obtained at a commercial vegetable market.

Pathogenicity for plants and insects has not been determined.

The average genome size is $1,215 \mathrm{kbp}$. The guanine-pluscytosine content of the DNA is $35.5 \mathrm{~mol} \%$, as determined by buoyant density, melting temperature, and HPLC methods.

The type strain is 0502 (= ATCC 49388).

Description of Acholeplasma palmae sp. nov. Acholeplasma palmae (pal'mae. L. fem. gen. n. palmae, of a palm tree, referring to the plant from which the organism was isolated).
Cells are primarily coccoid, ranging in diameter from 300 to $500 \mathrm{~nm}$. Cells lack true cell walls. Nonmotile. Colonies on solid medium containing $0.8 \%$ Noble agar usually have the appearance of fried eggs. Chemoorganotroph. Acid is produced from glucose. Does not hydrolyze arbutin, arginine, or urea. Agar colonies do not hemadsorb guinea pig erythrocytes.

Cholesterol or serum is not required for growth.

The temperature range for growth is 18 to $37^{\circ} \mathrm{C}$; optimum growth occurs at $30^{\circ} \mathrm{C}$.

Serologically distinct from other Acholeplasma species.

Isolated from the crown tissues of a palm (Cocos nucifera) tree with lethal yellowing disease in Jamaica.

Apparently not pathogenic for some leafhoppers; plant pathogenicity has not been determined.

The average genome size is $1,610 \mathrm{kbp}$. The guanine-pluscytosine content of the DNA is $30.0 \mathrm{~mol} \%$, as determined by buoyant density, melting temperature, and HPLC methods.

The type strain is $\mathbf{J} 233$ (= ATCC 49389).

\section{REFERENCES}

1. Aluotto, B. B., R. G. Wittler, C. O. Williams, and J. E. Faber. 1970. Standardized bacteriologic techniques for characterization of $M y$ coplasma species. Int. J. Syst. Bacteriol. 20:35-58.

2. Carle, P., D. L. Rose, J. G. Tully, and J. M. Bové. 1992. The genome size of spiroplasmas and other mollicutes. IOM Lett. 2:263.

3. Carle, P., C. Saillard, and J. M. Bové. 1983. DNA extraction and purification. Methods Mycoplasmol. 1:295-299.

4. Carle, P., C. Saillard, and J. M. Bové. 1983. Determination of guanine plus cytosine content of DNA. Methods Mycoplasmol. 1:301-308.

5. Clark, T. B., J. G. Tully, D. L. Rose, R. Henegar, and R. F. Whitcomb. 1986. Acholeplasmas and similar nonsterol-requiring mollicutes from insects: missing link in microbial ecology. Curr. Microbiol. 13:11-16.

6. Clyde, W. A., Jr. 1983. Growth inhibition tests. Methods Mycoplasmol. 1:405-410.

7. Eden-Green, S. 1983. Culture techniques for plant mycoplasmas. Methods Mycoplasmol. 2:235-241.

8. Eden-Green, S., and P. G. Markham. 1987. Multiplication and persistence of Acholeplasma spp. in leafhoppers. J. Invertebr. Pathol. 49:235-241.

9. Eden-Green, S., P. G. Markham, R. Townsend, D. B. Archer, M. F. Clark, and J. G. Tully. 1985. Plant pathogenicity and transmission tests with Acholeplasma spp. isolated from coconut palms in Jamaica. Ann. Appl. Biol. 106:439-449.

10. Eden-Green, S., and J. G. Tully. 1979. Isolation of Acholeplasma spp. from coconut palms affected by lethal yellowing disease in Jamaica. Curr, Microbiol. 2:311-316.

11. Edward, D. G. 1947. A selective medium for pleuropneumonia-like organisms. J. Gen. Microbiol. 1:238-243.

12. Gardella, R. S., and R. A. Del Giudice. 1983. Hemagglutination, hemadsorption, and hemolysis. Methods Mycoplasmol. 1:379-384.

13. Gardella, R. S., R. A. Del Giudice, and J. G. Tully. 1983. Immunofluorescence. Methods Mycoplasmol. 1:431-439.

14. International Committee on Systematic Bacteriology Subcommittee on the Taxonomy of Mollicutes. 1979. Proposal of minimal standards for descriptions of new species of the class Mollicutes. Int. J. Syst. Bacteriol. 29:172-180.

15. McCoy, R. E., D. S. Williams, and D. L. Thomas. 1979. Isolation of mycoplasmas from flowers, p. 75-80. In R. E. McCoy and H. Su (ed.), Proceedings of the Republic of China-United States Cooperative Science Seminar, Symposium Series I. National Science Council, Taipai, Taiwan.

16. Neimark, H. C., and C. S. Lange. 1990. Pulsed-field electrophoresis indicates full-length mycoplasma chromosomes range widely in size. Nucleic Acids Res. 18:5443-5448.

17. Neimark, H. C., J. G. Tully, D. Rose, and C. Lange. 1992. Chromosome size polymorphism among mollicutes. IOM Lett. 2:261.

18. Pyle, L. E., L. N. Corcoran, B. G. Cocks, A. D. Bergemann, J. C. Whitley, and L. R. Finch. 1988. Pulsed-field electrophoresis indi- 
cates larger-than-expected sizes for mycoplasma genomes. Nucleic Acids Res. 16:6015-6025.

19. Razin, S., and J. G. Tully. 1970. Cholesterol requirement of mycoplasmas. J. Bacteriol. 102:306-310.

20. Rose, D. L., and J. G. Tully. 1983. Detection of $\beta$-D-glucosidase: hydrolysis of esculin and arbutin. Methods Mycoplasmol. 1:385389.

21. Rose, D. L., J. G. Tully, J. M. Bové, and R. F. Whitcomb. 1993. A test for measuring growth responses of mollicutes to serum and polyoxyethylene sorbitan. Int. J. Syst. Bacteriol. 43:527-532

22. Senterfit, L. B. 1983. Preparation of antigens and antisera. Methods Mycoplasmol. 1:401-404.

23. Somerson, N. L., J. P. Kocka, D. Rose, and R. A. Del Giudice. 1982. Isolation of acholeplasmas and a mycoplasma from vegetables. Appl. Environ. Microbiol. 43:412-417.

24. Toth, K. F., N. Harrison, and B. B. Sears. 1994. Phylogenetic relationships among members of the class Mollicutes deduced from rps3 gene sequences. Int. J. Syst. Bacteriol. 44:119-124.

25. Tully, J. G. 1983. Reflections on recovery of some fastidious mollicutes with implications of the changing host patterns of these organisms. Yale J. Biol. Med. 56:799-813.

26. Tully, J. G. 1983. Cloning and filtration techniques for mycoplasmas. Methods Mycoplasmol. 1:173-177.

27. Tully, J. G. 1983. Tests for digitonin sensitivity and sterol requirement. Methods Mycoplasmol. 1:355-362.

28. Tully, J. G. 1984. The family Acholeplasmataceae, genus Acholeplasma, p. 781-787. In N. R. Krieg and J. M. Holt (ed.), Bergey's manual of systematic bacteriology, vol. 1. Williams \& Wilkins Co., Baltimore.

29. Tully, J. G. 1989. Class Mollicutes: new perspectives from plant and arthropod studies, p. 1-31. In R. F. Whitcomb and J. G. Tully (ed.), The mycoplasmas, vol. 5. Academic Press, Inc., New York.

30. Tully, J. G., J. M. Bové, F. Laigret, and R. F. Whitcomb. 1993.
Revised taxonomy of the class Mollicutes: proposed elevation of a monophyletic cluster of arthropod-associated mollicutes to ordinal rank (Entomoplasmatales ord. nov.), with provision for familial rank to separate species with nonhelical morphology (Entomoplasmataceae fam. nov.) from helical species (Spiroplasmataceae), and emended descriptions of the order Mycoplasmatales, family Mycoplasmataceae. Int. J. Syst. Bacteriol. 43:378-385.

31. Tully, J. G., D. L. Rose, R. F. Whitcomb, K. J. Hackett, T. B. Clark, R. B. Henegar, E. Clark, P. Carle, and J. M. Bové. 1987. Characterization of some new insect-derived acholeplasmas. Isr. J. Med. Sci. 23:699-703.

32. Tully, J. G., R. F. Whitcomb, K. J. Hackett, D. L. Rose, J. M. Bové, P. Carle, D. L. Williamson, and T. B. Clark. 1994. Taxonomic descriptions of eight new non-sterol-requiring mollicutes assigned to the genus Mesoplasma. Int. J. Syst. Bacteriol. 44:685-693.

33. Tully, J. G., R. F. Whitcomb, D. L. Rose, K. J. Hackett, E. Clark, R. B. Henegar, P. Carle, and J. M. Bové. 1990. Current insight into the host diversity of acholeplasmas. Zentralbl. Bakteriol. (Suppl.) 20:461-467.

34. Weisburg, W. G., J. G. Tully, D. L. Rose, J. P. Petzel, H. Oyaizu, D. Yang, L. Mandelco, J. Sechrest, T. G. Lawrence, J. Van Etten, J. Maniloff, and C. R. Woese. 1989. A phylogenetic analysis of the mycoplasmas: basis for their classification. J. Bacteriol. 171:64556467.

35. Whitcomb, R. F. 1983. Culture media for spiroplasmas. Methods Mycoplasmol. 1:147-158.

36. Williamson, D. L., J. G. Tully, D. L. Rose, K. J. Hackett, R. Henegar, P. Carle, J. M. Bové, D. E. Colflesh, and R. F. Whitcomb. 1990. Mycoplasma somnilux sp. nov., Mycoplasma luminosum $\mathrm{sp}$ nov., and Mycoplasma lucivorax sp. nov., new sterol-requiring mollicutes from firefly beetles (Coleoptera: Lampyridae). Int. $\boldsymbol{J}$. Syst. Bacteriol. 40:160-164. 